The Limits of Imagination WORDSWORTH, YEATS, AND STEVENS 
Digitized by the Internet Archive in 2015

https://archive.org/details/limitsofimaginat00hele 


\section{The Limits of Imagination}

$\nexists$ WORDSWORTH, YEATS, and STEVENS

\section{HELEN REGUEIRO}

Cornell University Press Ithaca and London 
Cornell University Press gratefully acknowledges a grant from the Andrew F. Mellon Foundation that aided in bringing this book to publication.

\section{Copyright (C) 1976 by Cornell University}

All rights reserved. Except for brief quotations in a review, this book, or parts thereof, must not be reproduced in any form without permission in writing from the publisher. For information address Cornell University Press, 124 Roberts Place, Ithaca, New York 14850.

First published 1976 by Cornell University Press.

Published in the United Kingdom by Cornell University Press Ltd., 2-4 Brook Street, London W1Y 1AA.

Material from George Seferis, Collected Poems 1924-1955, translated by Edmund Keeley and Philip Sherrard (copyright (C) 1967 by Princeton University Press; Princeton Paperback, 1975), pp. 15, 47, 95, and 147-149, is reprinted by permission of Princeton University Press.

International Standard Book Number 0-8014-0994-2

Library of Congress Catalog Card Number 76-13663

Printed in the United States of America by York Composition Co., Inc. Librarians: Library of Congress cataloging information appears on the last page of the book. 


\section{For Samuel Elam}


I am sorry for having let a broad river pass through my fingers without drinking a single drop.

-George Seferis, "Mythistorema" 